\title{
Rare Cause of Dysphagy: Giant Polypoid Esophageal Well- Differentiated Liposarcoma
}

\author{
Ladislav Mica ${ }^{a}$ Duri Gianom ${ }^{\mathrm{a}}$ Beata Bode ${ }^{\mathrm{c}}$ Peter Jaklin $^{\mathrm{b}}$ \\ Albert Hollinger ${ }^{\mathrm{a}}$ \\ Departments of a Surgery and ' Internal Medicine, Spital Männedorf, Männedorf, \\ and 'Institute of Surgical Pathology, University Hospital of Zürich, Zürich, \\ Switzerland
}

\section{Key Words}

Well-differentiated polypoid liposarcoma - Esophagus · MDM2 - CDK4

\begin{abstract}
Liposarcoma represents one of the most frequent (10-20\%) malignant mesenchymal tumors in the adult, affecting mostly the soft tissue of extremities, the trunk or the retroperitoneum. This tumor type occurs exceptionally rarely in the gastrointestinal tract with only few cases described in the literature. In this case we present a 73-year-old male patient who was admitted due to loss of weight, anorexia and postprandial emesis with dysphagy. Gastrographin esophagography failed to make precise diagnostics. CT scan of the upper gastrointestinal tract revealed a large esophageal tumor filling out the whole length of the esophagus. The tumor was removed by parasternocleidomastoidal approach with a stapler. Histopathological examination revealed a well-differentiated liposarcoma (grade I). Well-differentiated liposarcomas are characterised by amplified material of the 12q13-15 chromosomal region, present in the form of giant or ring chromosomes and leading to the overexpression of MDM2 and CDK4 genes. MDM2 and CDK4 proteins can be detected immunhistochemically, which was the case in the reported tumor. Overexpression of these proteins leads to suppression of tumor suppressor genes, leading to increased cell survival.
\end{abstract}

\section{Introduction}

Liposarcoma represents one of the most frequent (10-20\%) malignant mesenchymal tumors in the adult. Cytogenetically, three types of liposarcoma can be distinguished: (I) well- and dedifferentiated liposarcoma, both containing amplifications of the 12q13-15 in form of giant or ring chromosomes, (II) myxoid and round cell liposarcoma (MRCL) showing typically balanced $\mathrm{t}(12 ; 16)$ or $\mathrm{t}(12 ; 22)$ translocation, and (III) pleomorphic 


\begin{tabular}{c|l|l|l}
$\begin{array}{c}\text { CaseReportsin } \\
\text { Gastroenterology }\end{array}$ & $\begin{array}{l}\text { Case Rep Gastroenterol 2007;1:7-14 } \\
\text { Dol: } 10.1159 / 000104225\end{array}$ & Published online: June 20, 2007 & $\begin{array}{l}\text { @ 2007 S. Karger AG, Basel } \\
\text { ISSN 1662-0631 } \\
\text { www.karger.com/crg }\end{array}$ \\
\hline
\end{tabular}

liposarcoma with complex heterogenic karyotype alterations. Well-differentiated liposarcoma usually occurs in the retroperitoneum or in the deep soft tissue of the extremities (mostly high) or trunk [1-3]. It is extremely rare in the esophagus and causes unspecific clinical findings such as epigastric pain, dysphagy and persistent nausea. To our knowledge esophageal liposarcoma was first described by Mansour in 1983 [3]. To date only 14 esophageal liposarcomas have been described. In this case report we describe a 73-year-old male patient with a giant, pedunculated, polypoid esophageal welldifferentiated liposarcoma originating in the cervical esophagus to the gastroesophageal junction. This is the first case of esophageal well-differentiated liposarcoma with immunohistochemically proven overexpression of MDM2 and CDK4. MDM2 (mutated double minute) is a negative regulator of p53 [4]; after binding to p53 it may attach a polyubiquitin chain to $\mathrm{p} 53$. Once polyubiquitinated, $\mathrm{p} 53$ is destined to degradation by the proteasomal pathway. An induction of MDM2 in a tumor may shift the balance between apoptosis and survival towards survival.

\section{Case Report}

A 73-year-old male patient was admitted due to weight loss and anorexia. He had chronical retrosternal pain and postprandial vomiting since four weeks. Concomitantly this patient suffered progredient vascular encephalopathy and macroangiopathy IV caused by an escalated diabetes mellitus type II (NIDDM) with a HbAI $\mathrm{I}_{c}$ of $9.3 \%$. Three years earlier, he had undergone a right hemicolectomy due to moderately differentiated adenocarcinoma. Two coincidental inflammatory fibroid polyps were found in the terminal ileum.

Initial endoscopy of the upper gastrointestinal tract showed a mass obstructing the distal cervical esophagus to the gastroesophageal junction with no mucosal leasons (fig. 1). Additional esophagography with gastrographin confirmed the findings of a long-distance esophageal obstruction of unknown origin ( $\underline{\mathrm{fig}} .2)$. A CT scan of the caudal cervical organs to abdominal organs revealed a heterogenous esophageal mass not directly separable from the esophageal wall (fig. 3). No further neoplasias were found in the abdomen. A resection at the mucosal level was performed without complications. Following the resection the patient was on parenteral nutrition for 5 days. Recovery was uneventful. 12-week follow-up showed a patient in an improved nutritional state and again fully socially integrated.

\section{Findings}

\section{Macroscopy}

Intraoperatively the tumor could be easily separated from the esophageal lumen with no adhesions to the wall. The tumor was proximally attached to the esophageal wall by a slender stalk (diameter of $1 \mathrm{~cm}$ ). Resection at the esophageal level was performed by stapler technique. The resected specimen consisted of the tumor and was $20 \mathrm{~cm}$ long with a diameter of 4.5 to $5.5 \mathrm{~cm}$. The mucosal surface of the mass showed no ulcerations or necrosis (fig. 4).

\section{Histopathological Examination}

Microscopically (fig. 5 ) the tumor was covered by bland squamous epithelium with no dysplasia. The main mass of the polyp consisted of sheaths of adipocytes of variable size and often hyperchromic, enlarged and pleomorphic nuclei (inset a, arrow). The adipocytes showed nuclear immunohistochemical positivity in a reaction with antibodies 


\begin{tabular}{c|l|l|l}
$\begin{array}{c}\text { CaseReportsin } \\
\text { Gastroenterology }\end{array}$ & $\begin{array}{l}\text { Case Rep Gastroenterol 2007;1:7-14 } \\
\text { DOl: 10.1159/000104225 }\end{array}$ & Published online: June 20, 2007 & $\begin{array}{l}\text { @ 2007 S. Karger AG, Basel } \\
\text { ISSN 1662-0631 } \\
\text { www.karger.com/crg }\end{array}$ \\
\hline
\end{tabular}

against MDM2 protein (Zymed, Basel, dilution 1:50) (inset b, arrow) and CDK4 (not shown). No nonlipogenic or high-grade areas were identified. A diagnosis of a welldifferentiated liposarcoma was done. The resection margin of the tumor stalk contained tumor tissue.

\section{Discussion}

Lipogenic tumors of the gastrointestinal tract are extremely rare. They are mainly found in the mucosa or submucosa of the terminal ileum and large bowel. To our knowledge the first case was described by Mansour et al. in 1983 [3]. Only 14 cases of esophageal liposarcomas were reported up to date [1-3, 5-18] but without immunohistochemical analysis. Age varies between 43 and 73 years and male:female ratio is 1.16:1 [5]. The clinical finding may include dysphagy, odynophagy, retrosternal pain, respiratory distress, anemia, tumor regurgitation and sudden death by asphyxia. Misleading findings in gastroscopy, esophageal manometry and esophagography may be found. There are no pathognomonic symptoms or signs, and differential diagnosis includes fibrovascular polyp, fibrolipoma, achalasia, bezoars and indirect narrowing by mediastinal tumors. Only surgical resection and histological examination allows a precise diagnosis $[11,17,18]$. Atypical adipocytes and immunohistochemichal expression of MDM2 and/or CDK4 should not be found in fibrovascular polyps or fibrolipomas.

Surgical treatment varies from endoscopic resection, transcervical, simple enucleation or transgastric resection. In this case we preferred the transcervical approach to have an option for gut interponate. The most reliable prognostic factors of this tumor are histologic subtype, malignancy grade, location and surgical radicality. In patients with other types of liposarcomas survival varies between 7 and 104 months $[3,8,10,11]$.

The analysis of MDM2 was positive in this case. MDM2 is a negative regulator of $\mathrm{p} 53$, a tumor suppressor gene which, once activated, leads to cell cycle arrest and apoptosis by the mitochondrial pathway. MDM2 has beside a zincfinger domain and p53 binding domain a ringfinger domain. A ringfinger has E2 activity and combined with a p53 binding domain (E3) covalently binds ubiquitin residues to p53. Once ubiquitinated p53 is destined for degradation by the proteasomal pathway [19]. Therefore, induction of MDM2 leads to a suppression of p53 on the proteome level and may shift the cell toward survival (fig. 6). The hypothetical tumor suppressive effect of proteasomal inhibition may be misleading due to a central role in the regulation of cellular transcriptome. To our knowledge a prediction of metastatic behavior after induction of MDM2 cannot be made.

In this case we found a well-differentiated grade I liposarcoma not radically resected. In the case of our 73-year-old patient we did not exceed adiuvant therapies due to a palliative situation. Our case is negligible because liposarcomas of the esophagus are extremely rare, but the differential diagnosis of a liposarcoma should be considered if there is an matching anamnesis. 


\begin{tabular}{c|l|l|l}
$\begin{array}{c}\text { CaseReportsin } \\
\text { Gastroenterology }\end{array}$ & $\begin{array}{l}\text { Case Rep Gastroenterol 2007;1:7-14 } \\
\text { Dol: 10.1159/000104225 }\end{array}$ & Published online: June 20, 2007 & $\begin{array}{l}\text { @ 2007 S. Karger AG, Basel } \\
\text { ISSN 1662-0631 } \\
\text { www.karger.com/crg }\end{array}$ \\
\hline
\end{tabular}

Fig. 1. Esophageal endoscopy. Intraluminal view shows esophageal obturation without (asterisk) mucosal ulceration or necrotic areas.

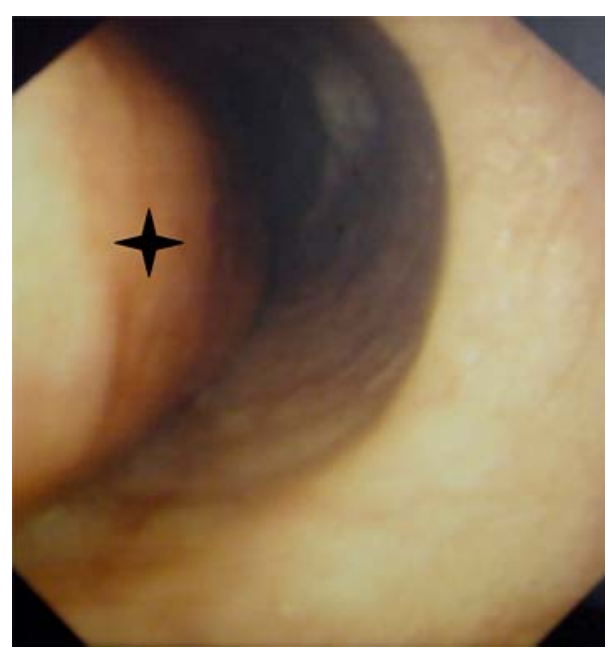

Fig. 2. Gastrographin esophagography. Narrowing of the esophageal lumen by a mass of unknown origin. Residual lumen is on the ventral side (arrows).

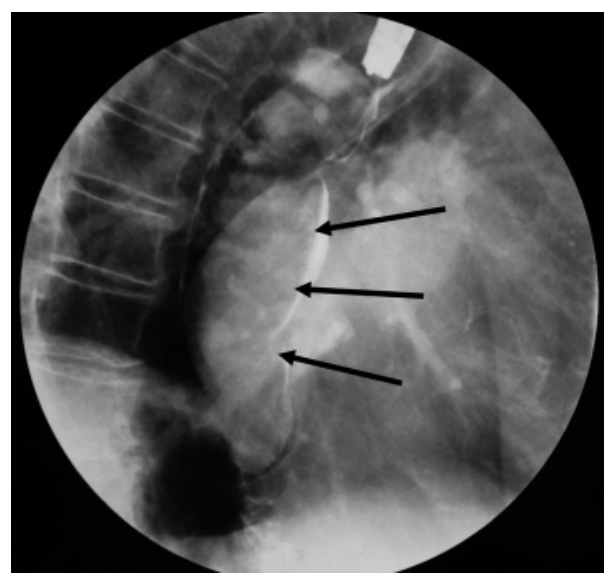




\begin{tabular}{c|l|l|l}
$\begin{array}{c}\text { Case Reportsin } \\
\text { Gastroenterology }\end{array}$ & $\begin{array}{l}\text { Case Rep Gastroenterol 2007;1:7-14 } \\
\text { Dol: } 10.1159 / 000104225\end{array}$ & Published online: June 20, 2007 & $\begin{array}{l}\text { @ 2007 S. Karger AG, Basel } \\
\text { ISSN 1662-0631 } \\
\text { www.karger.com/crg }\end{array}$ \\
\hline
\end{tabular}

Fig. 3. Contrast cervicothoracal CT scan. Frontal reconstructions revealed a long tumor mass filling the whole thoracal esophagus, without mediastinal infiltration.

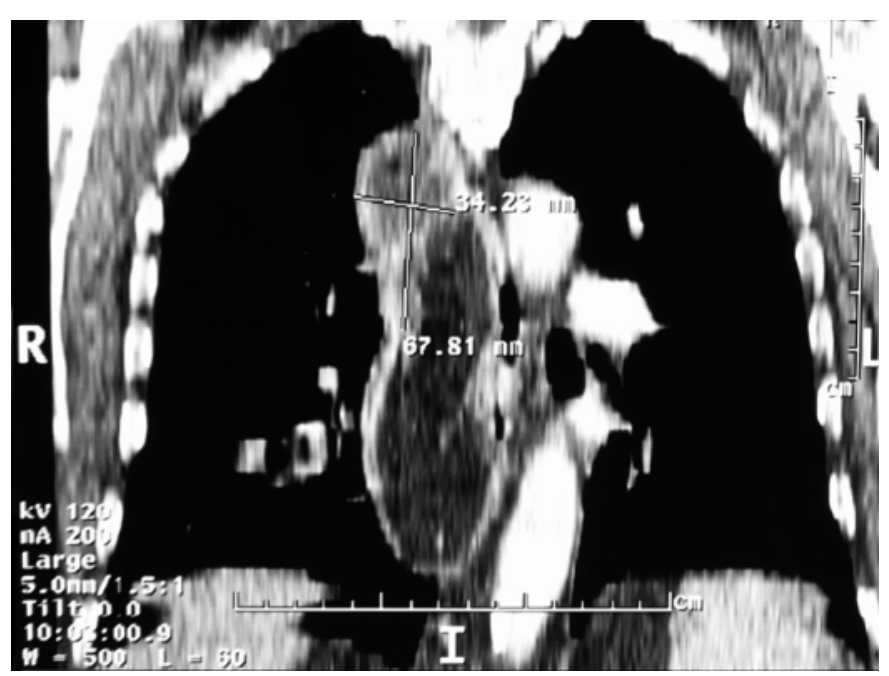

Fig. 4. Intraoperative macroscopic view. Large pedunculated tumor mass with $20 \mathrm{~cm}$ length and a diameter of $4.5-5.5 \mathrm{~cm}$.

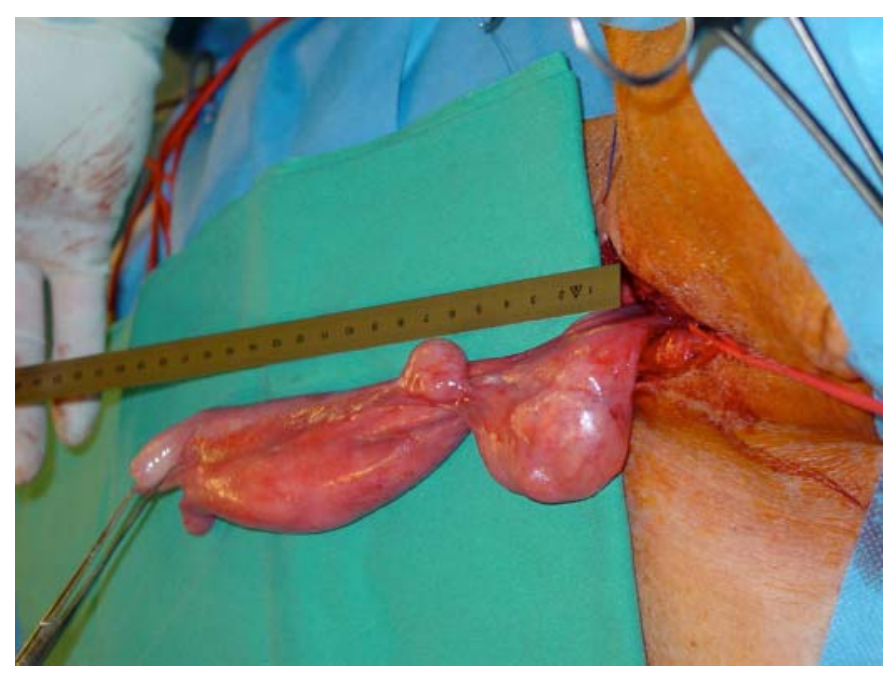




\begin{tabular}{c|l|l|l}
$\begin{array}{c}\text { Case Reportsin } \\
\text { Gastroenterology }\end{array}$ & $\begin{array}{l}\text { Case Rep Gastroenterol 2007;1:7-14 } \\
\text { Dol: 10.1159/000104225 }\end{array}$ & Published online: June 20, 2007 & $\begin{array}{l}\text { I 2007 S. Karger AG, Basel } \\
\text { ISSN 1662-0631 } \\
\text { www.karger.com/crg }\end{array}$ \\
\hline
\end{tabular}

Fig. 5. Histopathologically normal squamous epithelium covered tumor mass consisting of lipoblasts with hyperchromic nuclei (inset a, arrow). Immunohistochemically, nuclear expression of MDM2 was demonstrated (inset $b$, arrow).

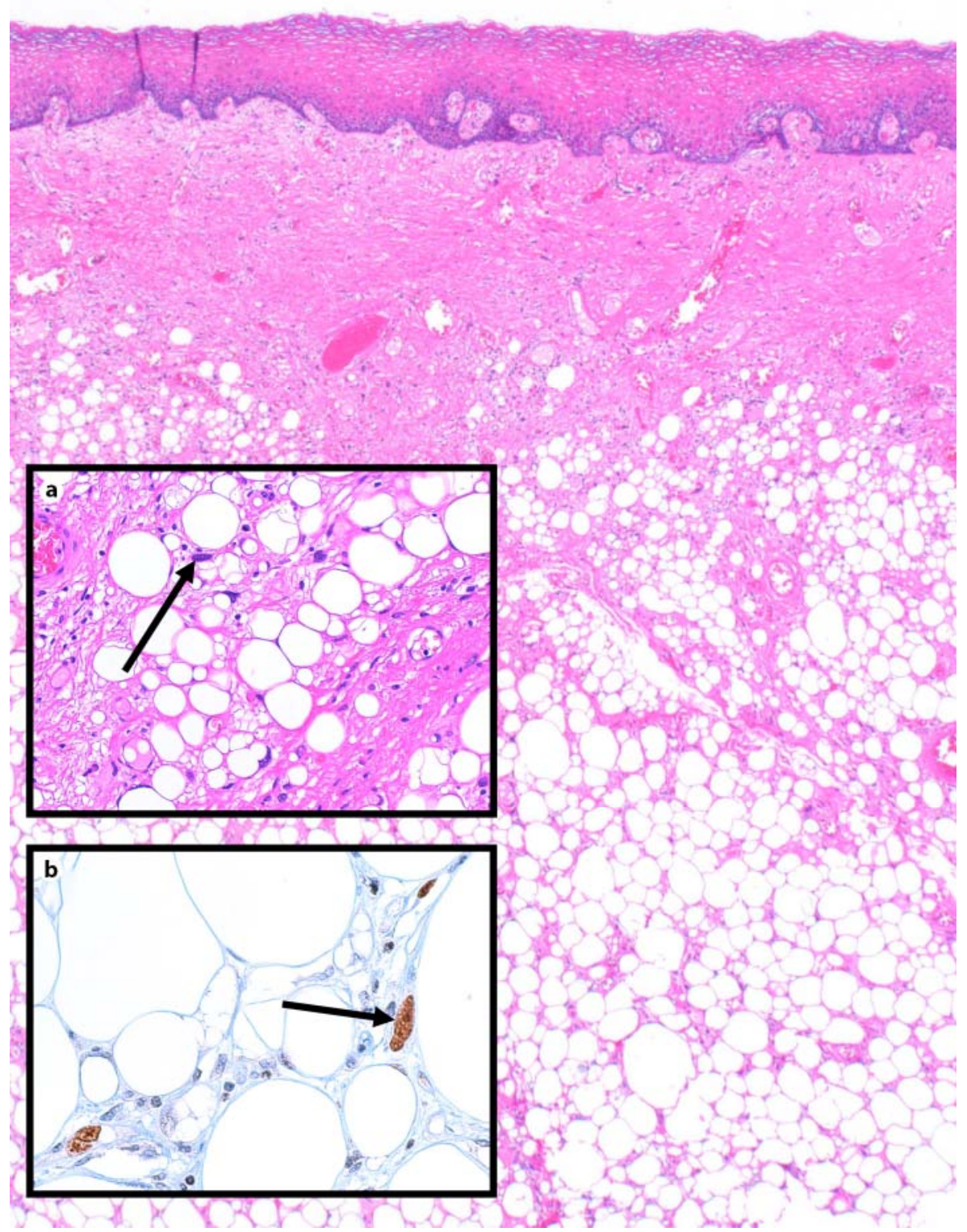


Fig. 6. Schematic overview of the MDM2 and p53 signalling pathway. The induction of MDM2 leads to suppression of $\mathrm{p} 53$ by proteasomal degradation. The inhibition of the tumor suppressor gene p53 leads to suppression of the mitochondrial apoptotic pathway and to survival of the cells.

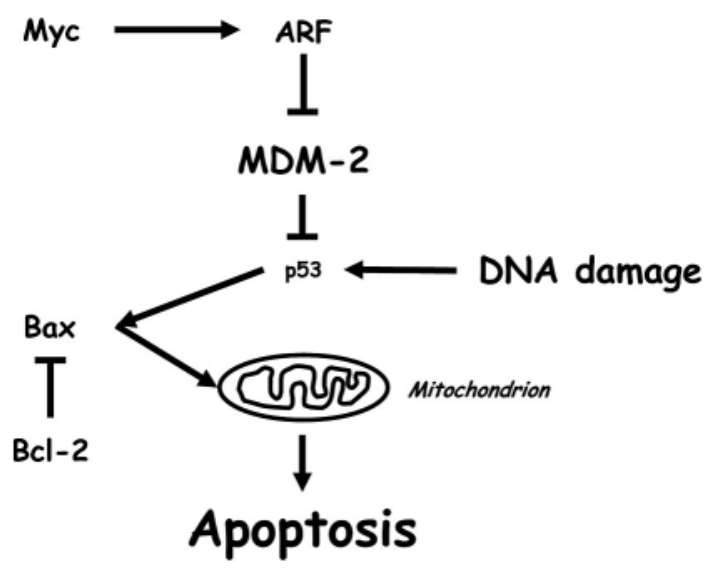




\begin{tabular}{c|l|l|l}
$\begin{array}{c}\text { CaseReportsin } \\
\text { Gastroenterology }\end{array}$ & $\begin{array}{l}\text { Case Rep Gastroenterol 2007;1:7-14 } \\
\text { DOl: 10.1159/000104225 }\end{array}$ & Published online: June 20, 2007 & $\begin{array}{l}\text { @ 2007 S. Karger AG, Basel } \\
\text { ISSN 1662-0631 } \\
\text { www.karger.com/crg }\end{array}$ \\
\hline
\end{tabular}

\section{References}

1 Weiss SW, Goldblum JR: Liposarcoma; in Weiss SW, Goldblum JR (eds): Enzinger and Weiss's, ed 4. Philadelphia, Mosby Harcourt, 2001, pp 641-662.

2 Garcia M, Buitrago E, Bejarano PA, Casillas J: Large esophageal liposarcoma: a case report and review of the literature. Arch Pathol Lab Med 2004;128:922-925.

3 Mansour KA, Fritz RC, Jacobs DM, Vellios F: Pedunculated liposarcoma of the esophagus: a first case report. J Thorac Cardiovasc Surg 1983;86:447-450.

4 Würl P, et al: Prognostic relevance of C-terminal Mdm2 detection is enhanced by p53 positivity in soft tissue sarcomas. Diagn Mol Pathol 1997;6:249-254.

5 Liakakos TD, Troupis TG, Tzathas C, Spirou K, Nikolaou I, Ladas S, Karatzas GM: Primary liposarcoma of the esophagus: a case report. World J Gastroenterol 2006;12:1149-1152.

6 Garcia M, Buitrago E, Bejarano PA, Casillas J: Large esophageal liposarcoma: a case report and review of the literature. Arch Pathol Lab Med 2004;128:922-925.

7 Bak YT, Kim JH, Kim JG, Lee CH, Lee KN, Choi YH, Kim HJ: Liposarcoma arising in a giant lipomatous polyp of the esophagus. Korean J Intern Med 1989;4:86-89.

8 Yates SP, Collins MC: Case report: recurrent liposarcoma of the oesophagus. Clin Radiol 1990;42:356-358.

9 Baca I, Klempa I, Weber JT: Liposarcoma of the esophagus. Eur J Surg Oncol 1991;17:313-315.

10 Cooper GJ, Boucher NR, Smith JH, Thorpe JA: Liposarcoma of the esophagus. Ann Thorac Surg 1991;51:1012-1013.

11 Boggi U, Viacava P, Naccarato AG, Giulianotti PC, di Candio G, Battolla L, Mosca F: Giant pedunculated liposarcomas of the esophagus: literature review and case report. Hepatogastroenterology 1997;44:398-407.

12 Salis GB, Albertengo JC, Bruno M, Palau G, Gonzalez Villaveiran R, Lombardo D, Villafane V, Zorraquin C, Ghigliani M: Pedunculated liposarcoma of the esophagus. Dis Esophagus 1998;11:68-71.

13 Temes R, Quinn P, Davis M, Endara S, Follis F, Pett S, Wernly J: Endoscopic resection of esophageal liposarcoma. J Thorac Cardiovasc Surg 1998;116:365-367.

14 Mandell DL, Brandwein MS, Woo P, Som PM, Biller HF, Urken ML: Upper aerodigestive tract liposarcoma: report on four cases and literature review. Laryngoscope 1999;109:1245-1252.

15 Ruppert-Kohlmayr AJ, Raith J, Friedrich G, Regauer S, Preidler KW, Szolar DH: Giant liposarcoma of the esophagus: radiological findings. J Thorac Imaging 1999;14:316-319.

16 Beaudoin A, Journet C, Watier A, Mongeau CJ, Chagnon M, Beaudry R: Giant liposarcoma of the esophagus. Can J Gastroenterol 2002;16:377-379.

17 Chung JJ, Kim MJ, Kim JH, Lee JT, Yoo HS, Kim KW: Imaging findings of giant liposarcoma of the esophagus. Yonsei Med J 2003;44:715-718.

18 Brehant O, Pessaux P, Hennekinne-Mucci S, Barriere E, D’Aubigny N, Aube C, Boyer J, Arnaud JP: Giant pedunculated liposarcoma of the esophagus. J Am Coll Surg 2004;198:320-321.

19 Muratani M, Tansey WP: How the ubiquitin-proteasome system controls transcription. Nat Rev Mol Cell Biol 2003;4:192-201. 